\title{
Synthesis, Characterization and Chromatographic Applications of Antimicrobial Cryogels
}

\section{Antimikrobiyal Kriyojellerin Sentezi, Karakterizasyonu ve Kromatografik Uygulamaları}

\section{Research Article}

\section{Kadir Erol}

Hitit University, Osmancık Ömer Derindere Vocational Higher School, Department of Property Protection and Safety, Corum, Turkey.

\section{A BSTRACT}

\begin{abstract}
Antibacterial materials, in the last years, have become an important center of attention against diseases beA cause of pathogenic bacteria. Within the scope of this study, antimicrobial poly(2-hydroxyethyl methacrylateglycidyl methacrylate), poly(HEMA-GMA), cryogels were synthesized and $\mathrm{Ag}(\mathrm{I})$ ions were immobilized to the structure through the amino acid L-Arginine. For characterization of the structure; swelling test, Fourier transform infrared (FT-IR) spectroscopy, scanning electron microscopy (SEM), surface area (BET), elemental analysis and ICP-OES methods were performed. The L-Arginine amino acid was used as an Ag (I) chelating ligand and the melittin protein adsorption capacity of cryogels was determined as $173.9 \mathrm{mg} / \mathrm{g}$ cryogel.
\end{abstract}

\section{Key Words}

Antimicrobial, cryogel, L-Arginine, $\mathrm{Ag}(\mathrm{I})$.

\section{öz}

atojenik bakterilerin sebebiyet verdiği hastalıklara karşı antibakteriyel malzemeler son yılllarda olduça önemli bir ilgi merkezi haline gelmiştir. Bu çalışma kapsamında antimikrobiyal poli(2-hidroksietil metakrilat-glisidil metakrilat), pol(HEMA-GMA), kriyojeller sentezlenmiş ve yapıya L-Arjinin aminoasidi üzerinden Ag(I) iyonları immobilize edilmiştir. Yapının karakterizasyonu için; şişme testi, Frouer dönüşümlü infrared (FT-IR) spektroskopisi, taramalı elektron mikroskobu (SEM), yüzey alanı (BET), elementel ve ICP-OES analizleri yapılmıştır. L-Arjinin amino asidinden $\mathrm{Ag}(\mathrm{I})$ şelatlayıcı ligand olarak yararlanılmış ve kriyojellerin melittin proteini için adsorpsiyon kapasitesi $173.9 \mathrm{mg}$ protein/g kriyojel olarak tespit edilmiştir.

\section{Anahtar Kelimeler}

Antimikrobiyal, kriyojel, L-Arjinin, Ag(I).

Article History: Received: Sep 9, 2016; Revised: Oct 2, 2016; Accepted: Jan 20, 2017; Available Online: Apr 1, 2017.

DOI: 10.15671/HJBC.2017.151

Correspondence to: K. Erol, Hitit University, Osmancık Ömer Derindere Voc. High. Sc., Dep. of Property Protection and Safety, Çorum, Turkey. 


\section{INTRODUCTION}

tudies on "Turkey's Important Plant Areas" $\checkmark$ have been dated back to the early 1990s. The results ofInfectious diseases caused by pathogenic bacteria are a threat to human health substantially. Silver metal, ion and compounds has been used as antibacterial material for the treatment of ulcers, wound healing and for the protection the food and water for centuries [1].

As promising alternatives, silver salts and pile metals, silver nanoparticles and the coordination complexes containing silver metal are increasingly being used as a new antibacterial agents [2-7].

Metal-organic coordination complexes, in recent years, because of their potential functional applications in areas such as separation, magnetism, catalysis, luminescence, and membrane gain a lot of attention alongside the interesting topology [8-13]. One of the materials used as membrane in the literature is cryogel.

Cryogel membranes, in the past decade, are polymeric structures been mainly used for adsorption processes. The cryogels, hydrogel derivatives, with three-dimensional mega pores are synthesized in frozen medium, by using water-soluble monomer/polymer solution in the presence of an initiator and an activator via free radical polymerization [14-16].

The frozen ice crystals work as porogen during polymerization, and the porous structure formed as a result of melting of frozen ice crystals is becoming quite helpful and useful material for chromatographic processes [17].

Among the other parameters making these polymers attractive, possessing larger pore sizes (up to 100 microns), high mechanical properties, high biocompatibility and reusability performance and the presence of the flow channel linked with each other can be mentioned [18-20].

In addition, the existence of macropores in cryogel structure allow the mass transfer of macromolecular compounds and the migration of the cells efficiently. Due to these properties, cryogel are used in tissue engineering [21-24], as the separation matrix in chromatographic processes [25-32] and as bioreactor [33,34].

The polymers with different characteristics can be obtained using the support material and surface modifications. The molecules selected according to the structure of the target molecule cryogel is coupled to the cryogel structure and the separation and purification process of target molecule is performed in accordance with affinity base. The cryogels, under favor of extremely to be open to modification, can have desired properties simply and quickly. Starting with this idea, to put the cryogel interaction with silver ions having antibacterial feature to have the cryogel with antibacterial properties is among the options that come to mind first.

Primarily, poly(2-hydroxyethyl methacrylateglycidyl methacrylate), poly(HEMA-GMA), cryogels were synthesized within the scope of this study. The cryogel was modified with the immobilization of L-arginine amino acid and finally reacted with the silver ion to obtain cryogels with antibacterial feature. The $\mathrm{Ag}(\mathrm{I})$ ion binding feature of the amino acid L-Arginine, was played a significant role in the selection as ligand [35]. The cryogels synthesized were characterized via swelling test, scanning electron microscope (SEM), Fourier-transform infrared spectroscopy (FT-IR), elemental analysis and surface area (BET) methods. In the last stage, the antibacterial and antifungal properties of cryogel has been examined.

\section{MATERIALS and METHODS}

\section{Material}

2-Hydroxyethyl methacrylate (HEMA), glycidyl methacrylate (GMA), ethylene glycol dimethacrylate (EGDMA), silver nitrate, ammonium persulfate (APS), sodium dodecyl sulphate (SDS), L-arginine, $\mathrm{N}, \mathrm{N}, \mathrm{N}^{\prime}, \mathrm{N}^{\prime}$-tetramethylethylenediamine (TEMED) and melittin (from honey bee venom) was supplied from the company Sigma (St. Louis, USA). All other chemicals are of analytical purity and ultra pure (18 M $\Omega . \mathrm{cm})$ water in all studies were used. 


\section{The Synthesis of Poly(HEMA-GMA) Cryogels}

GMA $(500 \mu \mathrm{L})$, HEMA $(5000 \mu \mathrm{L})$ and distilled water $(6500 \mu \mathrm{L})$ were mixed to obtain monomer phase. The disperse phase was obtained by mixing sodium dodecyl sulfate (SDS, $1 \mathrm{~g}$ ) distilled water (25.60 $\mathrm{mL}$ ) and EGDMA (2.4 $\mathrm{mL})$. Then the two phases were mixed with each other and cooled in an ice bath for 15 minutes before the addition of APS $(20 \mathrm{mg})$ and TEMED $(100 \mu \mathrm{L})$. The mixture obtained was remained at $-20^{\circ} \mathrm{C}$ for 24 hours.

The resulting cryogels were cut in the shape of membrane (disc). Until the sodium dodecyl sulfate and other monomer residues were removed from the medium and the washing water were clear, the cryogels were washed with distilled water in a rotator (Multi Bio RS-24 Biosan, Latvia) at the stirring rate of $10 \mathrm{rpm}$ with the change of washing water in every 15 minutes.

\section{The Immobilization of Silver onto Poly(HEMA- GMA) Cryogels}

The cryogel membranes (20 unit) was stirred firstly in the solution of $\mathrm{NaOH}(10 \mathrm{~mL}, 1 \mathrm{M})$ for 2 hours and then in the solution of arginine $(10 \mathrm{~mL}$, $5 \mathrm{mg} / \mathrm{mL}, \mathrm{pH} 5.0$ acetate buffer) for 24 hours after washed with distilled water several times, and finally in the solution of $\mathrm{AgNO}_{3}(10 \mathrm{~mL}, 5 \mathrm{mg} /$ $\mathrm{mL}$ ) for 6 hours. The membranes on which silver was immobilized were washed several times with distilled water and ethanol (Figure 1).

\section{Characterization Studies \\ Swelling Test}

The water retention capacity of poly(HEMA-GMA)Arg@Ag(I) was determined using distilled water. For this, dry cryogel membranes were carefully weighed, then thrown into the distilled water in the isothermal water bath and remained at $25^{\circ} \mathrm{C}$ for 30 minutes. Then membranes were placed into a filter paper to wipe quickly the water retained on the surface and weighed again to calculate the water-retention capacity.

The following equation was used to determine the capacity of water retention.

Water Retention Capacity $(\%)=\left[\left(\mathrm{W}_{\mathrm{s}}-\mathrm{W}_{\mathrm{o}}\right) / \mathrm{W}_{\mathrm{o}}\right] \times 100(1)$
In this equation, $W_{o}$ and $W_{s}$ are the weights $(g)$ of dry and water-retained membrane, respectively.

\section{SEM Analysis}

The surface morphology of cryogel membranes were examined using scanning electron microscopy (SEM, FEl/Quanta 450 FEG, USA). The membrane dried by lyophilisation was tailored for SEM analysis and was put on the double-sided tape on the SEM holder. The sample was then coated with a thin gold layer under vacuum. The sample obtained was, then, inserted into the SEM device and imaged at different magnification.

\section{FT-IR Analysis}

In the determination of the characteristic functional groups of poly(HEMA-GMA) cryogels, the Fourier transform infrared spectrometer (Thermo Scientific Nicolet 6700 FT-IR Spectrometer, USA) was used. Cryogels were dried and pulverized primarily (about $2 \mathrm{mg}$ ) and made into pellets homogeneously with anhydrous potassium bromide powder $(\mathrm{KBr})(98 \mathrm{mg}, \mathrm{IR}$ grade, Merck, Germany) and the FT-IR spectrum was obtained in the wave number range of 400 $4000 \mathrm{~cm}^{-1}$.

\section{Elemental Analysis}

About 2-3 mg of sample was dried totally put into the sample holder of the elemental analysis (Elementar vario PYRO cube, Germany) device. The analysis was performed at $1120^{\circ} \mathrm{C}$ for combustion tube and at $850^{\circ} \mathrm{C}$ for reduction tube to obtain the N\% in the sample.

\section{The Determined of Silver Amount Immobilized onto the Cryogels}

The ICP-OES (Spectro Arcos, Germany) device was used to determine the silver amount immobilized onto the poly(HEMA-GMA)-Arg cryogels. In this technique, the sample is excited by electromagnetic induction up to $10000 \mathrm{~K}$ by argon plasma and the quantity of elements excited are determined by the specific wavelength emitted. Plasma is obtained by the excitation of argon gas electromagnetically via a radio frequency $(\mathrm{RF})$ generator in induction coils. This happens by ionization of the incoming gas via hot plasma continuously. 


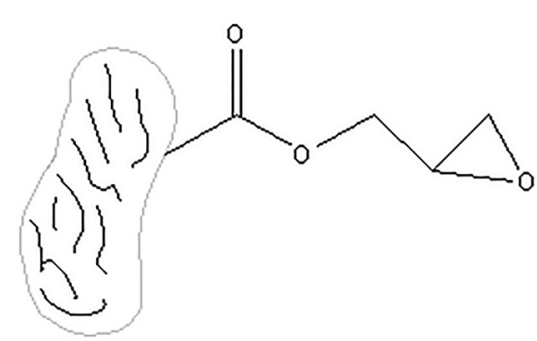

Poly(HEMA-GMA) Cryogel

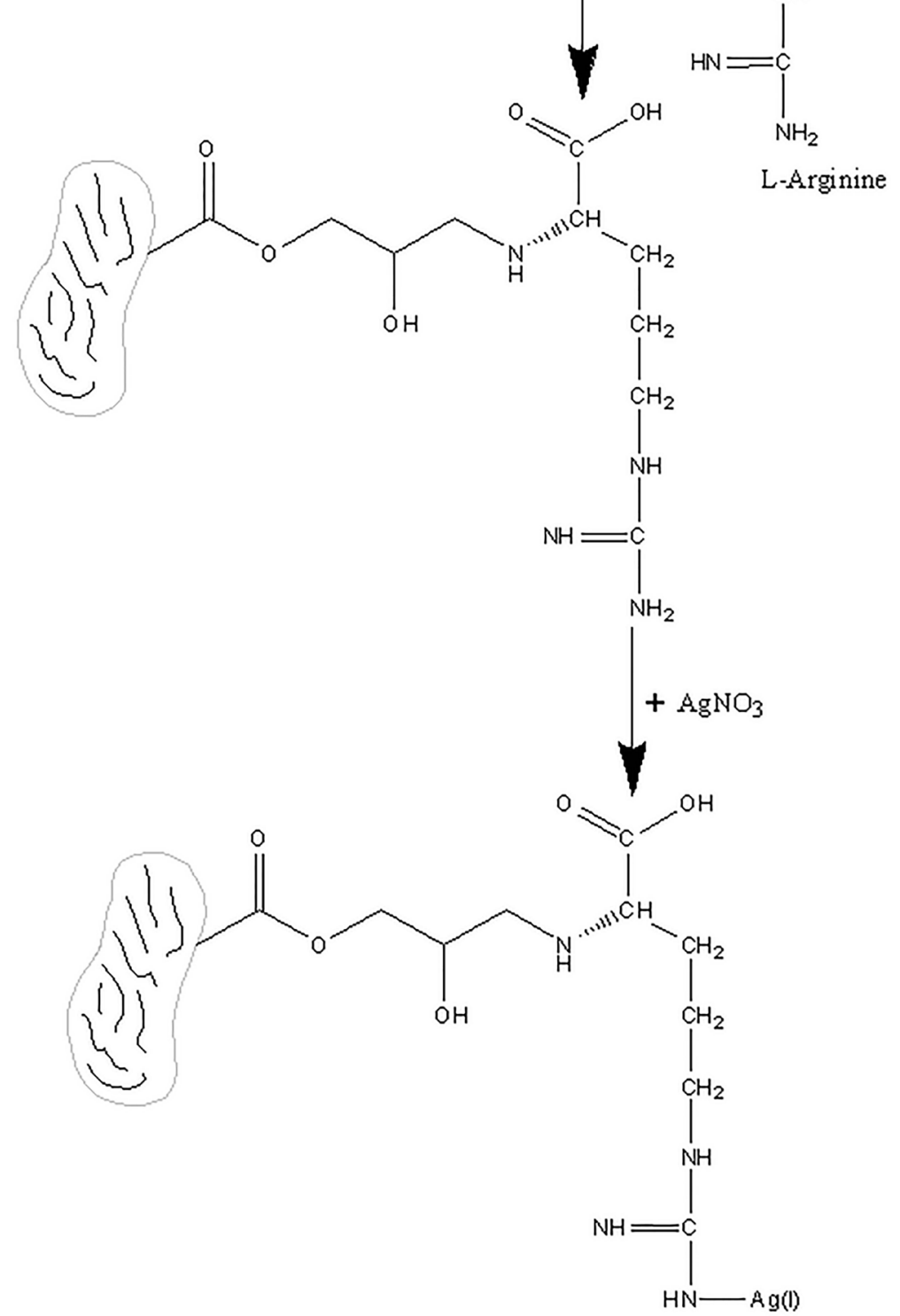

Poly(HEMA-GMA)-Arg@Ag(I)

Figure 1. The reaction mechanism of poly(HEMA-GMA)-Arg@Ag(I) cryogel formation. 


\section{Surface Area Analysis}

The specific surface area of the membranes was determined with the device BrunauerEmmett-Teller (BET; Quantachrome Autosorb ${ }^{\circledR}$ iQ-Chemi, USA). The cryogel samples dried with Iyophilisation were incubated at $35^{\circ} \mathrm{C}$ at $100 \mathrm{mbar}$ for 6 hours under vacuum to eliminate oxygen and moisture in the pores. Then, the cryogel samples were treated with nitrogen gas at room temperature.

\section{Antimicrobial Studies}

The micro broth dilution method was used to test the antimicrobial activities of cryogels. The microdilution testing protocol was selected to obtain the MIC [36]. Bacterial and C. globrata suspensions that were grown overnight in MuellerHinton broth and were standardized in doublestrength Mueller-Hinton broth to $108 \mathrm{CFU} / \mathrm{mL}$ using McFarland No: 0.5 standard solution. The dimethylsulfoxide $(0.002 \mathrm{~g} / \mathrm{mL}, 2 \mathrm{~mL})$ solution was used to prepare the stock solutions. $100 \mu \mathrm{L}$ suspension of each microorganism and compound tested were added into the wells, respectively. As a positive growth control, the sterile distilled water and the medium were used. The first well, in which there is no turbidity, was identified as the minimal inhibitory concentration (MIC) at the end of the incubation at $37^{\circ} \mathrm{C}$ for $24 \mathrm{~h}$. Chloramphenicol and ketoconazole were used as the standard antibacterial agent and whereas as antifungal agent, respectively.

\section{The Application of Adsorption/Desorption Using Melittin Protein}

The melittin protein, which is a small polypeptide and have antimicrobial feature, was selected to determine the adsorption/ desorption performance of poly(HEMA-GMA)-Arg@Ag (I) membranes against biomolecules [37]. The acetate buffer solution of $4 \mathrm{~mL}(\mathrm{pH}: 5)$ was mixed with melittin solution of $1 \mathrm{~mL}(100 \mathrm{mg} / \mathrm{L})$ and stirred in a rotator for 15 minutes. Then, in order to determine the protein concentration prior to adsorption, sample of $200 \mu \mathrm{L}$ was separated and the cryogel membrane was placed into the tube and stirred at $20 \mathrm{rpm}$ for 30 minutes. At the end of this period, the membrane was taken from the adsorption medium and to determine the protein concentration after adsorption a sample of $2 \mathrm{~mL}$ was taken from the adsorption environment. The adsorbed amount of melittin was determined via UV-VIS spectrophotometer (Double Beam PC 8 Auto Cell Scanning UVD-3200 Labomed, INC., USA) at $280 \mathrm{~nm}$ wavelength. The melittin adsorption capacity of cryogels was determined according to the following formula:

$q=\left[\left(C_{i}-C_{f}\right) \times V\right] / m$

Here, $\mathrm{q}$ is the amount of adsorption ( $\mathrm{mg} / \mathrm{g}$ ), $\mathrm{C}_{\mathrm{i}}$ is the concentration of melittin solution $(\mathrm{mg} / \mathrm{L})$ before adsorption, $C_{f}$ is the concentration of melittin solution $(\mathrm{mg} / \mathrm{L})$ after adsorption, $\mathrm{V}$ is the volume of the adsorption medium ( $L$ ) and $m$ is the mass of dry adsorbent $(\mathrm{g})$.

The $\mathrm{NaCl}$ solution $(10 \mathrm{~mL}$ ) of $1 \mathrm{M}$ was used for desorption studies. To determine the reusability of cryogels, $\mathrm{NaOH}$ solution $(10 \mathrm{~mL})$ of $50 \mathrm{mM}$ was used to regenerate cryogels exposed to desorption in between successive adsorptiondesorption cycles.

\section{RESULTS and DISCUSSION}

\section{Characterization Studies}

At the end of the swelling test, the swelling rate of the cryogel was determined as $301.3 \%$. Accordingly, the dry cryogel of $1 \mathrm{~g}$ has about water retention of $3 \mathrm{~g}$. According to the SEM image of cryogels examined, macro-pores and interconnected flow channels were drawn attention (Figure 2). When the FT-IR spectrum of poly(HEMA-GMA)-Arg cryogel was examined, the peaks were observed at $3442 \mathrm{~cm}^{-1}$ (alcohol, $-\mathrm{OH}$ ), at $2951 \mathrm{~cm}^{-1}$ (alkane, $\mathrm{C}-\mathrm{H}$ ) and $1731 \mathrm{~cm}^{-1}$ (carboxylic acid, $\mathrm{C}=\mathrm{O}$ ) (Figure 3-a). The peaks for poly(HEMA-GMA)-Arg@Ag (I) at $3442 \mathrm{~cm}^{-1}$ (alcohol, $-\mathrm{OH}$ ), at $2951 \mathrm{~cm}^{-1}$ (alkane, $\mathrm{C}-\mathrm{H}$ ), $1731 \mathrm{~cm}^{-1}$ (carboxylic acid, $\mathrm{C}=\mathrm{O}$ ) and also at $461 \mathrm{~cm}^{-1}(\mathrm{~N}-\mathrm{Ag}$ (I) bond) are clearly visible (Figure $3-b)$. These results confirm the inclusion of silver into the polymeric structure [38].

According to the elemental analysis results, the amount of L-arginine incorporated into the cryogel structure was estimated as $389 \mu \mathrm{mol} / \mathrm{g}$ polymer. The amount of $\mathrm{Ag}(\mathrm{I})$ immobilized onto the cryogels with the surface area of $6.289 \mathrm{~m}^{2} / \mathrm{g}$ was found as $140.5 \mu \mathrm{mol} / \mathrm{g}$ polymer. 


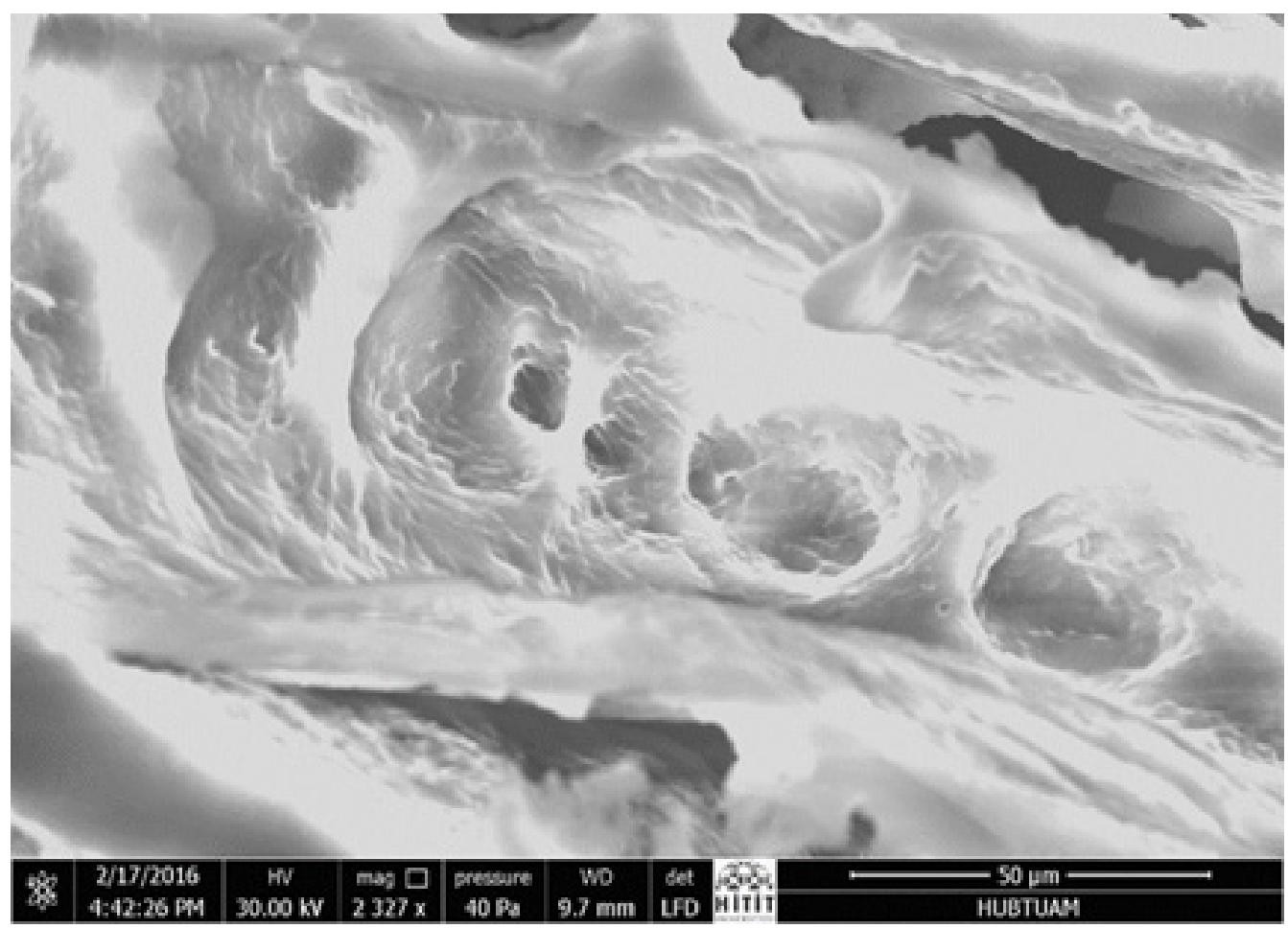

Figure 2. The SEM image of poly(HEMA-GMA)-Arg@Ag(I) cryogel.

\section{Antimicrobial Studies}

The microorganisms (Candida utilis, Escherichia coli, Enterobacter aerogenes, Pseudomanas aeruginosa, Bacillus subtilis, Staphylococcus aureus) were used to antimicrobial activity analysis of cryogel dispersion solution $(1 \mathrm{mg} / \mathrm{mL})$ prepared in DMSO-distilled water (1:1) mixture. At the end of the studies performed, the cryogel solution have shown antimicrobial activity and the minimum inhibitory concentration (MIC) was determined as $0.25 \mathrm{mg} / \mathrm{mL}$.

\section{Melittin Adsorption/Desorption}

The adsorption capacity of cryogels for melittin protein was estimated as $173.9 \mathrm{mg} / \mathrm{g}$ at the end of the adsorption-desorption experiments. This result indicates that the poly(HEMA-GMA)Arg@Ag(I) cryogels have effective adsorption performance and may be used in chromatographic processes. It has also been found to have $99 \%$ of melittin desorbed from the melittin-adsorbed cryogels (Figure 4). Thus, poly(HEMA-GMA)-Arg@ $\mathrm{Ag}(\mathrm{I})$ cryogels have reusability feature in the adsorption studies.

\section{CONCLUSION}

It can be reported at the end of the studies performed that poly(HEMA-GMA) -Arg @ Ag (I) cryogels have antimicrobial activity. In light of the data obtained, the materials under consideration is the promising materials to be used in medical applications. In addition, the high adsorption capacity of these cryogels is also advantageous in order to increase the diversity in chromatographic applications.

\section{ACKNOWLEDGEMENT}

Because of the contribution to the work, I would like to express my heartfelt thanks of Prof. Dr. Nevzat Şahin (19 Mayıs University, Faculty of Arts and Sciences, Department of Biology) and Asst. Assoc. Dr. Demet Tatar (Hittite University, Osmancik Ömer Derindere Vocational Higher School, Medical Services and Technical Division). 


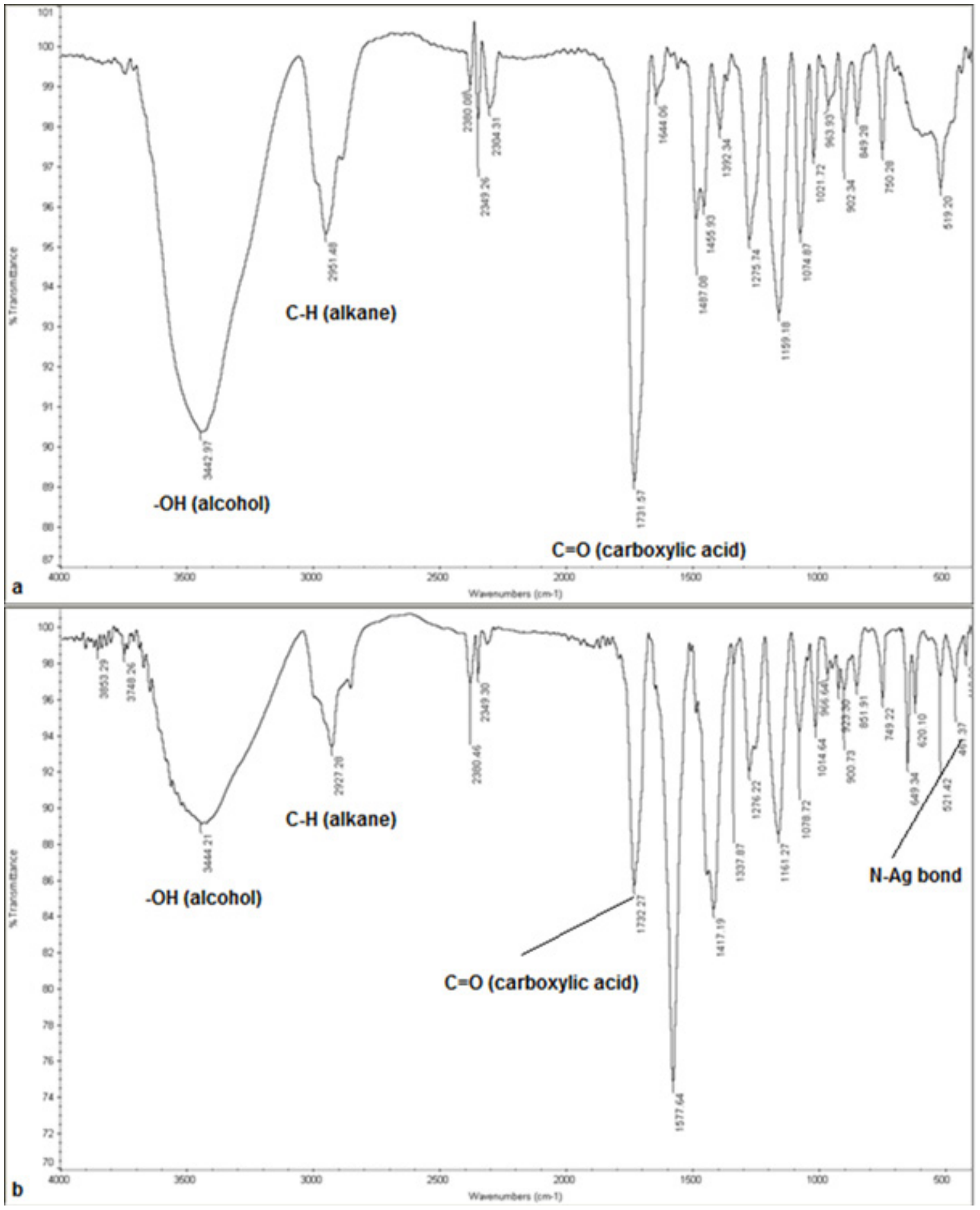

Figure 3. FT-IR spectra of a) Poly(HEMA-GMA)-Arg b) Poly(HEMA-GMA)-Arg@Ag(I) cryogels. 


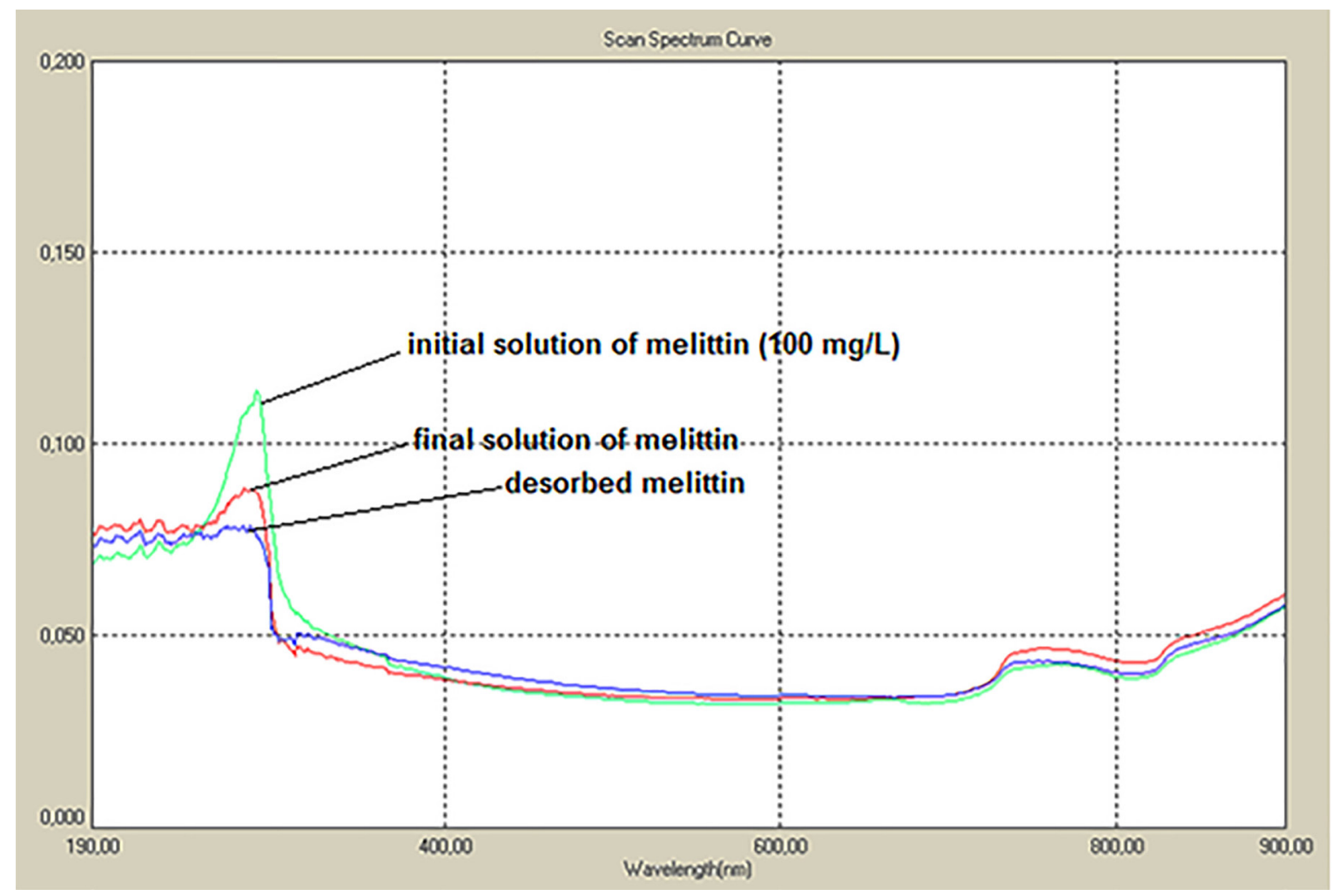

Figure 4. The UV-VIS spectrum (at $280 \mathrm{~nm}$ ) of desorbed melittin.

\section{References}

1. J. Alexander. History of the medical use of silver. Surg, Infect. (Larchmt), 10 (2009) 289-292.

2. S. Kittler, C. Greulich, J. Diendorf, M. Koller, M. Epple. Toxicity of Silver Nanoparticles Increases during Storage Because of Slow Dissolution under Release of Silver Ions Chem. Mater., 22 (2010) 4548-4554.

3. C. Greulich, D. Braun, A. Peetsch, J. Diendorf, B. Siebers, M. Epple, M. Koller. The toxic effect of silver ions and silver nanoparticles towards bacteria and human cells occurs in the same concentration range. RSC Advances, 2 (2012) 6981-6987.

4. S. Eckhardt, P.S. Brunetto, J. Gagnon, M. Priebe, B. Giese, K.M. Fromm. Nanobio silver: its interactions with peptides and bacteria, and its uses in medicine. Chem. Rev., 113 (2013) 4708-4754.

5. M. Rai, A. Yadav, A. Gade. Silver nanoparticles as a new generation of antimicrobials. Biotechnol. Adv., 27 (2009) 76-83.

6. L. Rizzello, P. Pompa. Nanosilver-based antibacterial drugs and devices: Mechanisms, methodological drawbacks, and guidelines. Chem. Soc. Rev., 43 (2014) 1501-1518.

7. S. Chernousova, M. Epple. Silver as antibacterial agent: ion, nanoparticle, and metal. Chem. Int. Ed., 52 (2013) 1636-1653.

8. Z.J. Lin, J. Lu, M. Hong, R. Cao. Metal-organic frameworks based on flexible ligands (FL-MOFs): structures and applications. Chem. Soc. Rev., 43 (2014) 5867-5895.
9. T.R. Cook, Y.R. Zheng, P.J. Stang. Metal-organic frameworks and self-assembled supramolecular coordination complexes: comparing and contrasting the design, synthesis, and functionality of metalorganic materials. Chem. Rev., 113 (2013) 734-777.

10. J.R. Li, Q. Yu, E.C. Sanudo, Y. Tao, X.H. Bu. An azido$\mathrm{Cu}(\mathrm{II})$-triazolate complex with utp-type topological network, showing spin-canted antiferromagnetism. Chem. Commun., 25 (2007) 2602-2604.

11. J. Jiang, O.M. Yaghi. Brønsted acidity in metal-organic frameworks. Chem. Rev., 115 (2015) 6966-6997.

12. L.B. Sun, X.Q. Liu, H.C. Zhou. Design and fabrication of mesoporous heterogeneous basic catalysts. Chem. Soc. Rev., 44 (2015) 5092-5147.

13. M.Y. Masoomi, A. Morsali. Applications of metalorganic coordination polymers as precursors for preparation of nano-materials. Coord. Chem. Rev., 256 (2012) 2921-2943.

14. F.M. Plieva, I.Y. Galaev, B. Mattiasson, Macroporous gels prepared at subzero temperatures as novel materials for chromatography of particulate-containing fluids and cell culture applications, J. Sep. Sci., 30 (2007) 1657-1671.

15. M.U. Kahveci, Z. Beyazkilic, , Y. Yagci, Polyacrylamide cryogels by photoinitiated free radical polymerization, J. Polym. Sci: Part A: Polym. Chem., 48 (2010) 49894994.

16. S. Reichelt, C. Abe, S. Hainich, W. Knolle, U. Decker, A. Prager, R. Konieczny, Electron-beam derived polymeric cryogels, Soft Matter, 9 (2013) 2484-2492. 
17. S. Hajizadeh, H. Kirsebom, A. Leistner, B. Mattiasson Composite cryogel with immobilized concanavalin A for affinity chromatography of glycoproteins, J. Sep. Sci., 35 (2012) 2978-2985.

18. F.X. Gao, X.L. Zhao, X.W. He, W.Y. Li, Y.K. Zhang, A $\mathrm{pH}$ and temperature dual-responsive macroporous molecularly imprinted cryogel for enhanced recognition capability towards ovalbumin, Anal. Methods, 5 (2013) 6700-6708.

19. B. Mattiasson, A. Kumar, Yu Galaev, Macroporous Polymers: Production Properties and Biotechnological/ Biomedical Applications, CRC Press, 2009.

20. K.J. Yao, J.X. Yun, S.C. Shen, F. Chen, In-situ graftpolymerization preparation of cation-exchange supermacroporous cryogel with sulfo groups in glass columns, J. Chromatogr. A, 1157 (2007) 246-251.

21. M. Andaç, F.M. Plieva, A. Denizli, I.Y. Galaev, B. Mattiasson, Poly(hydroxyethyl methacrylate)-based macroporous hydrogels with disulfide cross-linker Macromol. Chem. Phys., 209 (2008) 577-584.

22. T. Dispinar, W.V. Camp, L.J. De Cock, B.G. De Geest, F.E. Du Prez, Redox-responsive degradable PEG cryogels as potential cell scaffolds in tissue engineering, Macromol. Biosci., 12 (2012) 383-394.

23. Y. Hwang, C. Zhang, S. Varghese, Poly (ethylene glycol) cryogels as potential cell scaffolds: effect of polymerization conditions on cryogel microstructure and properties, J. Mater. Chem., 20 (2010) 345-351.

24. S. Reichelt, J. Becher, J. Weisser, A. Prager, U. Decker, S. Möller, A. Berg, M. Schnabelrauch, Biocompatible polysaccharide-based cryogels, Mater. Sci. Eng. C, 35 (2014) 164-170.

25. P. Arvidsson, F.M. Plieva, I.N. Savina, V.I. Lozinsky, S. Fexby, L. Bülow, I.Yu. Galaev, B. Mattiasson, Chromatography of microbial cells using continuous supermacroporous affinity and ion-exchange columns, J. Chromatogr. A, 977 (2002) 27-38.

26. C. Aydogan, M. Andac, , E. Bayram, R. Say, A. Denizli, Molecularly imprinted cryogel for I-glutamic acid separation, Biotechnol. Prog., 28 (2012) 459-466.

27. M.B. Dainiak, I.Yu. Galaev, A. Kumar, F.M. Plieva, B. Mattiasson, Chromatography of living cells using supermacroporous hydrogels, cryogels, Adv. Biochem. Eng. Biotechnol., 106 (2007) 101-127.

28. G. Ertürk, B. Mattiasson, Cryogels-versatile tools in bioseparation, J. Chromatogr., A 1357 (2014) 24-35.
29. A. Hanora, I.N. Savina, F.M. Plieva, V.A. Izumrudov, B. Mattiasson, I.Y. Galaev, Direct capture of plasmid DNA from non-clarified bacterial lysate using polycationgrafted monoliths, J. Biotechnol., 123 (2006) 343-355.

30. A. Kumar, F.M. Plieva, I.Yu. Galaev, B.M. Mattiasson, Affinity fractionation of lymphocytes using a monolithic cryogel, J. Immunol. Methods, 283 (2003) 185-194.

31. L. Wang, S.C. Shen, X.J. He, J.X. Yun, K. Yao, S.J. Yao, Adsorption and elution behaviors of bovine serum albumin in metal-chelated affinity cryogel beds, Biochem. Eng. J., 42 (2008) 237-242.

32. K.J. Yao, J.X. Yun, S.C. Shen, L.H. Wang, F. Chen, X.M. $Y u$, Protein adsorption in supermacroporous cryogels with embedded nanoparticles, Biochem. Eng. J., 36 (2007) 139-146.

33. G.R. Jespersen, A.L. Nielsen, F. Matthiesen, H.S. Andersen, H. Kirsebom, Dual application of cryogel as solid support in peptide synthesis and subsequent protein-capture, J. Appl. Polym. Sci., 130 (2013) 43834391.

34. A. Kumar, V. Bansal, J. Andersson, P.K. Roychoudhury, B. Mattiasson, Supermacroporous cryogel matrix for integrated protein isolation immobilized metal affinity chromatographic purification of urokinase from cell culture broth of a human kidney cell line, J. Chromatogr. A, 1103 (2006) 35-42.

35. V.W.M. Lee, H. Li, T.C. Lau, R. Guevremont, K.W.M. Siu. Relative silver $(I)$ ion binding energies of $\alpha$-amino acids: a determination by means of the kinetic method. Journal of the American Society for Mass Spectrometry, 9 (1998) 760-766.

36. R. Schwalbe, L.S. Moore, A.C. Goodwin, Antimicrobial Susceptibility Testing Protocols. CRC Press, pp. 75-79.

37. X. Wu, A.K. Singh, X. Wu, Y. Lyu, A.K. Bhunia, G. Narsimhan, Characterization of antimicrobial activity against Listeria and cytotoxicity of native melittin and its mutant variants, Colloids and Surfaces B: Biointerfaces, 143 (2016) 194-205.

38. B. Morzyk-Ociepa, D. Michalska, Vibrational spectra of 1-methyluracilate complex with silver $(\mathrm{I})$ and theoretical studies of the $1-\mathrm{MeU}$ anion, Spectrochimica Acta Part A, 59 (2003) 1247-1254. 
